\title{
Application of Greedy Algorithm on Traffic Violation Enforcement
}

\author{
Nur Kumala Dewi \\ STMIK Muhammadiyah Jakarta, Indonesia \\ Email:nkd.mandori@gmail.com \\ Arman Syah Putra \\ STMIK Insan Pembangunan, Indonesia \\ Email: armansp892@gmail.com
}

Received: 05 December 2020; Accepted: 14 January 2021; Published: 08 February 2021

\begin{abstract}
The background of this research is how the application of the algorithm in traffic control systems, with the Greedy algorithm, the system will decide what action and what punishment will be given to traffic offenders on the highway, with the Greedy algorithm, the decisions taken will be based on data and facts. based on existing laws, so decisions made based on law and the human side cannot influence the decisions to be taken by the system based on the application of the Greedy algorithm. The research method used in this study uses literature reviews by reading many previous research journals, it will be able to add knowledge and deepen the research we are doing this time, with the literature review method, we will be able to find new problems and can be used as new research because The literature review is very helpful for our research this time. The system that is being used is using CCTV and can determine what decisions and punishments will be given to traffic offenders, through evidence based on images taken by cameras placed at red lights or corners of the capital's highway, the system this has been active effectively but with the implementation of the algorithm will increase. This research will produce a system proposal and be able to find out whether the application of the Greedy algorithm is correct and can help the current system by implementing the algorithm, so the existing system is more perfect. The main contribution of this research is that the use of the Greedy algorithm can help control the traffic system to enforce the law.
\end{abstract}

Index Terms: Greedy Algorithm, control, Traffic, System.

\section{Introduction}

In a smart city, surveillance and enforcement are included in a system system that is made to help various parties run the wheels of work which is carried out every day with a system that is mostly done to help the community and parties related to systems connected to other systems [1], it can be done with one door means that many systems can be done with one door, lots of work and can be done in one place with a system that is connected to many systems, it must be able to use or analyze a data and be able to produce new data that has been analyzed [2], the application of the Greedy algorithm is one of the methods used. applied to this research by applying the Greedy algorithm, the system can draw conclusions like humans with the Greedy algorithm, the system will run itself without having to be monitored by humans [3]. The main objective of this research is to know how the application of the Greedy algorithm in solving traffic violation problems [4], on the highway can the application of the Greedy algorithm help solve existing problems [5].

The current system is using CCTV. At the red light and also applied to every corner of the highway with CCTV [6] surveillance and action can be switched from human to system with the presence of this TV side, the image is taken and converted into data and the data is generated for As evidence of electronic ticketing with CCTV [7], surveillance and action are carried out by the system and the application of the Greedy algorithm in this study will assist data processing in the form of analysis so that proof of the Yes ticket can produce a claim and produce articles on the electronic ticket [8].

Traffic supervision and enforcement are still handled manually [9], by placing the police on every corner of the capital's road [10], with the police on the ground on the main road, supervision and action can be maximized, but if the police are not present, the supervision and repression will be less than optimal [11]. Therefore, the police are still deemed to need to be on the road, with this system, supervision and prosecution can be carried out in a neatly structured 
system [12], this system is designed to be able to assist the police to supervise and take action, everything is done based on a system so that no action is taken [13], can be picky and and all the guilty will receive the punishment [14].

The method used in this study uses literature reviews by reading many previous studies related to current research with literature reviews [15], so that it can find many new problems and can be the basis for future research with literature reviews, which will add to the insight of the researchers and can help researchers discover new problems [16].

The problem raised in today's research is the application of the Greedy algorithm to a traffic control and enforcement system with the application of the Greedy algorithm [17]. Can the system that is already running be more optimal [18], the current system uses CCTV that is placed on the side of the road to retrieve evidence from law enforcement in traffic, but only uses evidence as a reference in law enforcement with the Greedy algorithm [18], then the data that has been obtained will be analyzed and can be used to prosecute articles to be determined in law enforcement in the traffic sector [19].

The solution to be achieved in this research is how technology can help solve problems in the traffic sector [20], especially with the application of the Greedy algorithm [21]. With this algorithm, the system problems that occur in the traffic field can be solved before there has been no algorithm applied to the system [22]. Algorithm for traffic violations on the road Therefore the application of the Greedy algorithm will be able to help solve traffic problems, especially in the field of law enforcement on the highway [23].

\section{Literature Review}

The D-Greedy algorithm is substantially superior to the greedy algorithm [24]. However, it will have almost the same results if the input string is long or random, but even though the difference is not significant [25], based on the above experiments the Greedy algorithm is never superior to the D-Greedy algorithm [26].

Traffic Law Enforcement is a system created by the Semarang Police Traffic Police in collaboration with related agencies of the Semarang city government as a model for law enforcement against [27], traffic violations based on the technology-based E-TLE system for traffic control, Semarang Police, responding to the demands of the public who want the enforcement of a clean and transparent legal system. and fair [28].

The Greedy Algorithm can assist companies in carrying out distribution which can find the optimal path for production (activities) to run smoothly [29].

The greedy algorithm in terms of $\mathrm{n}$ reduced base space dimensions can be preserved when using a randomized training set of $\mathrm{N}$ cardinalities that scale polynomials at $\mathrm{n}$ [30]. The numerical illustration here uses the parametric dimensions $d$ and $t$, and it is noted that if $t$ and $d$ are the same the error is greater at $d=64$ than from $d=16$ [31].

The development of transportation in Indonesia, especially Jakarta, has been very great, with the existence of Trans Jakarta, MRT, LRT, adding to the development of Jakarta to a smart city by connecting all modes of transportation [32], Jakarta as a city that is an example of the development of smart cities in Indonesia, is also a role model the development of smart cities throughout Indonesia [33].

IoT in a mode of transportation is very important because there are existing media in several modes of transportation, such as online motorcycle taxis, with IoT media, so data transmission and data reception can be sent quickly and can be processed immediately [34].

The application of internet media is very much needed in all aspects of life, and one of them is in the field of games and can be applied to the learning of special needs children [35].

Part of a smart city is smart transportation, with a system that is connected to several modes of transportation [36], it will be able to help people travel and the government reduce congestion caused by people leaving without using private vehicles [37].

The implementation of ERP or Electronic Road Pricing in Jakarta can be a solution to solve congestion that occurs in Jakarta [38], Jakarta, which is the capital city as a role model for all cities throughout Indonesia [39].

The application of learning has used online learning, general learning and religious learning [40], with the use of technology with online media learning can be anywhere and anytime, learning and teaching can be done online or offline [41].

The use of a cloud database on a smart transportation system will greatly assist the system in storing data and being able to process data for the sake of the future [42], so that the data can be used later to perform data searches and the data can be used as evidence to determine the driver who made a mistake [43].

Storage of vehicle data on the Cloud system will make it easier for the data to be processed, and used as data on vehicle service using the Cloud system, so all vehicle data will be neatly stored and there can be known deficiencies of the vehicle [44], and can be repaired if a deficiency is found and and can be repaired immediately by therefore neat data will make everything easier [45].

Intelligent transportation control can be done with one door, namely the Regional Government or the Police, with proper control and management, smart transportation will be more efficient and the system used will be able to help the community in dealing with problems, especially congestion problems [46]. occurs if the highway is not managed optimally, therefore proper management and control of an intelligent transportation system will help it [47]. 
The development of smart transportation is carried out by almost all developing and large cities in the world [48], therefore transportation is considered important for a city with the development of smart transportation so that the city will be able to adopt a smart city system and will continue to develop for the benefit of the city community [49].

In the development of intelligent transportation drivers are an important part of the transportation system, with good drivers the system will run smoothly and the occurrence of road errors will be reduced [50], therefore drivers must be surveyed to get results, the types of good drivers must be explained and described for the development of smart transportation in a large and developing city [51].

Smart transportation is the development of a system made for public transportation that can be used by many people, with public transportation, the community can reduce the use of private transportation and can reduce congestion [52], with smart transportation, the community will be greatly helped in terms of vehicles, congestion and payment. therefore the development of smart transportation is needed [53].

The use of smart transportation is carried out in a simulation in order to find out whether the proposed smart transportation system can maximize [54], existing transportation and the system created can help the wider community in using public facilities so that the use of private facilities such as cars can be minimized [55].

The classification in the supervision of the vehicle system on the highway, yes, the system is made based on various types of classification [56], for example the type of car, the color of the car, the year the car and the driver, if this classification is successful, the types of violations will be known and the types of action can be given directly without having to know the system or the human side [57].

Supervision of automatic vehicles can be carried out in an intelligent transportation system, with the use of automatic vehicles, the driver can run the vehicle without having to touch the vehicle, with an automatic vehicle [58], an intelligent transportation system must be created and suitable for automatic vehicle transportation, therefore the compilers of system adjustments must be in accordance automatic systems in vehicles [59].

Passenger vehicles in a smart transportation system are very important, because passengers can affect the course of the vehicle with excess vehicle passengers, accidents can occur, therefore passengers are limited to one vehicle [60], vehicle passengers must also not exceed the weight limit, even if the vehicle passenger is small but if the vehicle is heavy If the vehicle weighs more, the vehicle is at risk of an accident [61], for example by lifting a lot of goods so that the vehicle occupants and goods must also be limited [62].

Payment systems that are integrated with smart transportation will greatly assist the public in making transactions [63], especially in the field of transportation, with integrated payments, the use of electronic money will be very much needed, therefore the use of electronic money has begun to be socialized long before the integrated payment system begins [64].

The character development process associated with smart transportation can also affect the characteristics of a city community [65]. Therefore character development needs to be studied and developed so that the characteristics of a city community can be more advanced and can accept the concept of a smart city [66].

The best scheme for the development of smart transportation must be developed as well as possible [67]. Therefore the scheme must be made by experts who understand the transportation sector with a good scheme that will produce a good system and also the system development will continue until the system reaches perfection with a system that is good. both will help people in the development of smart transportation [68].

Introducing the attributes of smart transportation is very necessary because what is needed in the development of smart transportation must be explained one by one [69]. Therefore, what is needed must be clear and can be developed again at a later date with a clear system, so the system will continue to develop and develop to the point where better [70].

Database classifier using SQL then classifying data will be much easier and can help programmers solve a case in the field of programming and databases can also be made more quickly so that they can be connected with programs that have been made [71].

The use of characteristics in intelligent transportation can greatly assist the Police in terms of monitoring and enforcement, for example in monitoring cars and prosecuting drivers who commit violations with the same pattern [72].

The pattern contained in intelligent transportation is a pattern that can be used in overcoming problems in the transportation system, for example the congestion pattern of the violation pattern can be used as a basis for monitoring and action by the Police, with this pattern a time structure is created that can be used as the basis for a enforcement [73].

Data mining patterns on smart transportation can be used in terms of data searches carried out by traffic offenders on the highway, with the right data mining pattern it will find patterns of violations committed by offenders on the highway [74].

Artificial intelligence developed in smart transportation can continue to be done by knowing what variables can be developed so that people can solve problems in the transportation sector, for example, traffic jams that occur every day on every highway in the capital, therefore what patterns are used must be clear in order to be able to solve existing problems [75].

The pattern in a Framework explains that the smart transportation system can be used by all people so that problems in the community can be reduced, for example, congestion using the Framework that has been made, the government can use this Framework to solve congestion problems or other problems caused by transportation [76]. 
An emergency pattern made in an intelligent transportation will generate something related to accidents and can help the police and the hospital in determining preparations so that they can prevent an accident early with an emergency pattern made so that the driver can know about the road which ones are good to use and which roads are not good for use therefore decrease the accident rate [77].

The development of smart transportation and smart payments can be integrated into a system that will make it easier for people to travel and use public transportation so that people can be more comfortable in using public facilities. Therefore, with this convenience the community will not use private facilities [78].

The pattern of extracting data using frequency can also be applied to intelligent transportation systems based on the frequency that is distributed to the car by using the frequency of the car can be monitored remotely and the car can be found out its whereabouts through the frequency emitted from a device planted in the car by transferring data using frequencies. will make it easier for the police to supervise and take action [79].

Research development patterns can also be done in pattern recognition by looking at the many problems that exist on the road [80], related to traffic and smart transportation. Research development patterns that use data mining will be able to identify problems that occur and be able to find solutions to problems that occur [81].

The use of patterns by using data mining will be able to assist intelligent transportation in developing the existing transportation system with the development of smart transportation, the government will create a system that can help all parties solve existing problems with a smart system so that all will be integrated into one and will create a new system that will help all [82].

In a regional head election, the transportation system will change based on who leads the area.Therefore, with a smart leader, the intelligent transportation system will definitely be created well with regional head elections that can represent the people, papers, people's problems will be solved based on the system smart city developments [83].

An application was created to help humans to make work easier, with an application so many things can be made easier, for example, the transportation system, with a smart transportation system, the community and transportation parties will be connected with an application, and this application can help the community monitor the performance of the transportation system [84].

Jakarta is the capital of the state of Indonesia Jakarta is a city that is growing rapidly and has started to adopt the concept of a smart city with a concept that has already been implemented, so slowly Jakarta will become a metropolitan capital that has many systems with many systems, so the community will be greatly helped, for example payment transportation using electronic money so that people do not need to carry cash and can help the community because many promotions are used for electronic money [85].

The use of patterns can also be used in smart transportation, many of which can be used in making patterns in transportation. Adjust the congestion patterns, patterns of vehicle use and patterns of public facilities. patterns that can be known in developing a good system for a smart transportation [86].

\section{Greedy Algorithm Development}

The D-Greedy algorithm outperforms the Greedy algorithm substantially because it can produce a superstring with only half the size of the Greedy algorithm and the comparison between the Greedy and D-Greedy Algorithms [87].

The method used by the Greedy Algorithm is to form a solution from step by step and take the best decision in its determination, We can see an example of the method used by J.Webster \& M.Moshkov in determining the shorted distance from A-B. Where in the distribution, distance and time searches are carried out in order to be efficient. optimal. Where the results of the route search with the greedy algorithm method get a popular route through the city A-B-C-F-G$\mathrm{H}$ with a distance of $648 \mathrm{~km}$ [88].

The spiked covariance model was suggested by Johnstone to model the combined effect of a low-dimensional signal buried in high-dimensional noise. The parameter $\beta 0$ is the signal strength, $\mathrm{v} * \in \mathrm{Rp}$ is the nail planted which is assumed to be the $\mathrm{k}$-sparse unit-length vector. SNR is regulated by $\beta$ and $\mathrm{k}$ [89].

The development of the Greedy algorithm can be used by classifying the pattern of extracting data by extracting data, so the analysis of a Greedy algorithm will be clearer, therefore with the addition of the Greedy algorithm, the analysis of each violation will result in a lawsuit in the form of missing and data based on the ticket. can be accounted for legally what articles can be prosecuted in a ticket with the Greedy algorithm, the system will be assisted in analyzing an error committed by motorists on the highway with the Greedy algorithm so all decisions can be taken directly by the Greedy algorithm and results in instantaneous loss [90].

The current system is using CCTV and only a fine sentence with image media based on photo evidence obtained on the highway. Analyzing errors that have occurred in the field Therefore this Greedy algorithm will provide a decision that the offender has the right to receive a ticket or not by using the Greedy algorithm, so the system does not need to think again, so it can immediately decide whether the violation is entitled to get a ticket for his mistake [91].

In its development, the system used in the intelligent transportation system has adopted many existing transportation abroad, for example, is the implementation of Transjakarta, MRT, LRT, therefore with a very rapid development, the smart transportation system must develop according to the times, for example, the enforcement system by The police, who are named with this action system, are greatly assisted by this system, for example vehicle 
monitoring, vehicle enforcement and the most important thing is the decision to take a ticket, because the ticket action must be based on evidence that can punish the offenders. unlawful cross on the highway [92].

The pattern of traffic violations can be seen from the many types of violations committed by traffic violators, therefore traffic violations can be seen from the number of tickets that can be taken by the police, in taking action this pattern is important in terms of prosecution because the police do not want to commit it is futile to take action against traffic offenders, with the pattern of the police being able to find out what mistakes are traffic offenders in a place, with the right pattern the police can arrange the time to take action [93].

\section{Proposed System in Smart Transportation}

In this research, we produce a system proposal that will discuss how a Greedy algorithm can help solve the problem of monitoring and enforcement of traffic on the road with the Greedy algorithm, which will be able to assist the police in taking action in this case, it will reduce the police on the road.

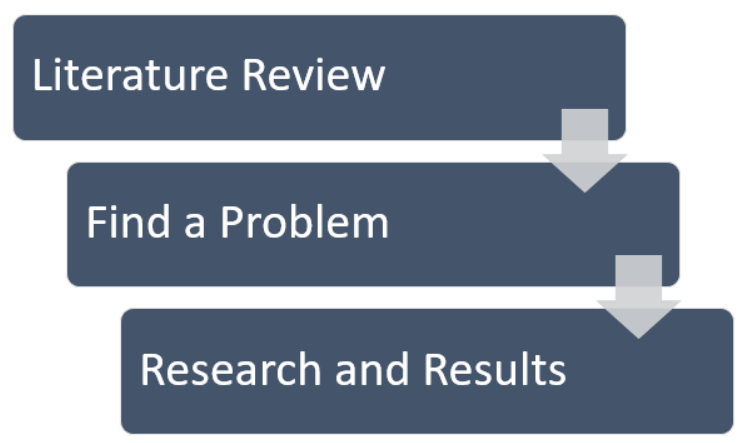

Fig. 1. Research Methods

Based on the picture above, it will be explained below:

\section{A. Literature Review}

In this first stage using a review literature study with this study it is hoped that the research can produce something new because the research is carried out based on previous research by reading journals related to research, now this research uses literature reviews by reading many journals by reading many journals. add knowledge to the author and can deepen the research that is being done.

\section{B. Find a Problem}

The problem is the goal of research Research that has a problem will have a goal that will be sought in future research with the problem, it will have a purpose and that research will be more focus.

\section{Research and Results}

Research is the most important part of a study with the right research, it will be able to solve a research problem. Research will also find solutions to the problems raised with the right research and use the right method.Then the results will produce valid data and can be used for later data this can be used in order to achieve maximum results.

The method used in this research is more focused on reviewing previous studies which have the same basic research thinking by reviewing similar journals, so many problems will be found and can also find problems that do not exist in previous research to complement the research. In the future, by reviewing it, researchers can explore research and have a strong theoretical basis so that they can find problems and can answer the problems raised in this research. Therefore, the issues raised must be in accordance with the latest research so that this research can be a reference for research in the future that will be disclosed in further research on There are sub conclusions.

At this stage the author makes a system proposal that will be able to make an existing system into a better system.The system will be explained in the picture and explanation below. 


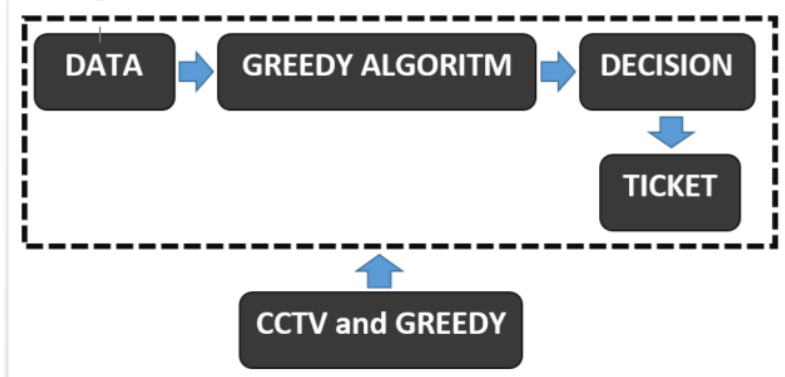

Fig. 2. The Proposed System

\section{Data}

The data in this proposed system is data obtained from CCTV that has been implemented by the police in order to supervise and enforce traffic on the highway, data is obtained after the rider commits a violation and the data is also used as evidence in making a claim in the form of a ticket.

\section{E. Greedy Algoritm}

The Greedy algorithm is applied after the data entered into the system and processed by the system using the analysis of the Greedy algorithm with the intention of generating new data to produce legal action in the form of a ticket.

\section{F. Decision}

The decision is taken after the Greedy algorithm draws conclusions from the data taken by CCTV [16], the new data will make a decision that legal action will be carried out in the form of a ticket.

\section{G. Tiket}

The ticket is issued based on the results of the analysis of the data processed using the Greedy algorithm and the ticket is intended to take legal action against offenders on the highway.

\section{H. CCTV and GREEDY}

The use of CCTV and the addition of the proposed system using the Greedy algorithm will make the existing system in the field of surveillance and enforcement be even better. This system will create a new system that can help the police in analyzing a traffic violation so that the work of the police can be far lighter.

The advanced features offered in the proposed system are how to process data and be able to produce the best decision in the field of traffic, in deciding a violation on the highway with the Greedy algorithm, all decisions will be processed and will produce the best decisions in the field of prosecution.

Based on the system proposal above, it can be concluded that the application of the Greedy algorithm in monitoring traffic systems is as follows

\section{Conclution}

Based on the research above, it can be concluded that. The use of the Greedy algorithm can help an existing system become a better system because the analysis of the Greedy algorithm can help analyze the data obtained by CCTV as the basis for ticket prosecution, the use of the Greedy algorithm also helps the police in making decisions in ticket prosecution. Future research by comparing several algorithms such as the AHP algorithm and the HNP algorithm, this comparison of several algorithms will find out which algorithm can be used to help solve problems of surveillance and prosecution carried out by the police on the highway.

This research produces something new in law enforcement in the traffic sector with the proposed system using the Greedy algorithm, so it can be used as material for system development that will be carried out in the future with the Greedy algorithm, so all decision making will be based on the system and will produce decisions that are best for law enforcement in traffic.

With the system that will be proposed this time, future research can be made by making applications, or real use and being able to apply them to existing systems, in order to see how this system can be successful or not, it will be part of the future research carried out at this time. 


\section{References}

[1] Y. Agarwal, K. Jain, and O. Karabasoglu, "Smart vehicle monitoring and assistance using cloud computing in vehicular Ad Hoc networks," Int. J. Transp. Sci. Technol., vol. 7, no. 1, pp. 60-73, 2018, doi: 10.1016/j.ijtst.2017.12.001.

[2] M. Agbali, C. Trillo, T. Fernando, I. A. Ibrahim, and Y. Arayici, "Conceptual Smart City KPI Model: A System Dynamics Modelling Approach,” Proc. 2nd World Conf. Smart Trends Syst. Secur. Sustain. WorldS4 2018, pp. 158-162, 2019, doi: 10.1109/WorldS4.2018.8611565.

[3] S. H. Ahmed, M. A. Yaqub, S. H. Bouk, and D. Kim, "Towards content-centric traffic ticketing in VANETs: An application perspective," Int. Conf. Ubiquitous Futur. Networks, ICUFN, vol. 2015-Augus, pp. 237-239, 2015, doi: 10.1109/ICUFN.2015.7182541.

[4] G. Aisyah and P. Bestari, "Implementation E-Tilang in Bandung to Increase Awareness of Cross as Moral Law Passed Citizenship (Civic Virtue)," vol. 251, no. 22, pp. 664-667, 2018, doi: 10.2991/acec-18.2018.148.

[5] Z. Al-Ars, S. van der Vlugt, P. Jääskeläinen, and F. van der Linden, "ALMARVI System Solution for Image and Video Processing in Healthcare, Surveillance and Mobile Applications,” J. Signal Process. Syst., vol. 91, no. 1, pp. 1-7, 2019, doi: $10.1007 / \mathrm{s} 11265-018-1423-2$.

[6] Z. Allam and P. Newman, "Redefining the Smart City: Culture, Metabolism and Governance," Smart Cities, vol. 1, no. 1, pp. 4-25, 2018, doi: 10.3390/smartcities1010002.

[7] B. A. Alpatov, P. V. Babayan, and M. D. Ershov, "Vehicle detection and counting system for real-time traffic surveillance," 2018 7th Mediterr. Conf. Embed. Comput. MECO 2018 - Incl. ECYPS 2018, Proc., no. June, pp. 1-4, 2018, doi: 10.1109/MECO.2018.8406017.

[8] A. A. Ambardekar and T. Advisor, "Efficient Vehicle Tracking and Classification for an Automated Traffic Surveillance System," 2007.

[9] M. Angelidou, A. Psaltoglou, N. Komninos, C. Kakderi, P. Tsarchopoulos, and A. Panori, "Enhancing sustainable urban development through smart city applications," J. Sci. Technol. Policy Manag., vol. 9, no. 2, pp. 146-169, 2018, doi: 10.1108/JSTPM-05-2017-0016.

[10] A. Appathurai, R. Sundarasekar, C. Raja, E. J. Alex, C. A. Palagan, and A. Nithya, "An Efficient Optimal Neural NetworkBased Moving Vehicle Detection in Traffic Video Surveillance System," Circuits, Syst. Signal Process., vol. 39, no. 2, pp. 734-756, 2020, doi: 10.1007/s00034-019-01224-9.

[11] P. April Insani, "Mewujudkan Kota Responsif Melalui Smart City," PUBLISIA (Jurnal Ilmu Adm. Publik), vol. 2, no. Smart City, pp. 25-31, 2017.

[12] P. Bellavista, F. Caselli, A. Corradi, and L. Foschini, "Cooperative vehicular traffic monitoring in realistic low penetration scenarios: The COLOMBO experience,” Sensors (Switzerland), vol. 18, no. 3, 2018, doi: 10.3390/s18030822.

[13] T. Berglund, A. Brodnik, H. Jonsson, M. Staffanson, and I. Söderkvist, "Planning smooth and obstacle-avoiding B-spline paths for autonomous mining vehicles," IEEE Trans. Autom. Sci. Eng., vol. 7, no. 1, pp. 167-172, 2010, doi: 10.1109/TASE.2009.2015886.

[14] T. M. A.-U.-H. Bhuiyan, M. Das, and M. S. R. Sajib, "Computer vision based traffic monitoring and analyzing from on-road videos," Glob. J. Comput. Sci. Technol., vol. 19, no. 2, 2019.

[15] A. Bondy, D. Sheslow, and L. T. Garcia, "An investigation of children's fears and their mothers' fears," J. Psychopathol. Behav. Assess., vol. 7, no. 1, pp. 1-12, 1985, doi: 10.1007/BF00961842.

[16] C. L. Bottasso, D. Leonello, and B. Savini, "Path planning for autonomous vehicles by trajectory smoothing using motion primitives," IEEE Trans. Control Syst. Technol., vol. 16, no. 6, pp. 1152-1168, 2008, doi: 10.1109/TCST.2008.917870.

[17] P. Cardullo and R. Kitchin, "Being a 'citizen' in the smart city: up and down the scaffold of smart citizen participation in Dublin, Ireland," GeoJournal, vol. 84, no. 1, 2019, doi: 10.1007/s10708-018-9845-8.

[18] J. Chang, L. Wang, G. Meng, S. Xiang, and C. Pan, "Vision-based occlusion handling and vehicle classification for traffic surveillance systems," IEEE Intell. Transp. Syst. Mag., vol. 10, no. 2, pp. 80-92, 2018, doi: 10.1109/MITS.2018.2806619.

[19] S. Chaudhuri and U. Dayal, "Data warehousing and OLAP for decision support," Lect. Notes Comput. Sci. (including Subser. Lect. Notes Artif. Intell. Lect. Notes Bioinformatics), vol. 1341, pp. 33-34, 1997, doi: 10.1007/3-540-63792-3_6.

[20] S. Chaudhuri and U. Dayal, "An Overview of Data Warehousing and OLAP Technology," SIGMOD Rec. (ACM Spec. Interes. Gr. Manag. Data), vol. 26, no. 1, pp. 65-74, 1997, doi: 10.1145/248603.248616.

[21] J. W. Choi, R. Curry, and G. Elkaim, "Path planning based on bézier curve for autonomous ground vehicles," Proc. - Adv. Electr. Electron. Eng. - IAENG Spec. Ed. World Congr. Eng. Comput. Sci. 2008, WCECS 2008, no. 2, pp. 158-166, 2008, doi: 10.1109/WCECS.2008.27.

[22] G. Corraro, F. Corraro, E. De Lellis, and L. Garbarino, "Flight tests of ADS-B traffic advisory system (ATAS) and performance comparison with other surveillance systems," AIAA Aerosp. Sci. Meet. 2018, no. 210059, 2018, doi: 10.2514/6.2018-0286.

[23] R. Cowley, S. Joss, and Y. Dayot, "The smart city and its publics: insights from across six UK cities," Urban Res. Pract., vol. 11, no. 1, pp. 53-77, 2018, doi: 10.1080/17535069.2017.1293150.

[24] M. Desai and A. Phadke, "Internet of Things based vehicle monitoring system," IFIP Int. Conf. Wirel. Opt. Commun. Networks, WOCN, pp. 1-3, 2017, doi: 10.1109/WOCN.2017.8065840.

[25] N. K. Dewi et al., "Konsep Aplikasi E-Dakwah Untuk Generasi Milenial Jakarta penting dalam menyiarkan agama Islam . Dengan media dakwah yang tepat maka akan bisa menyiarkan agama Islam dengan maksimal dengan media dakwah yang tepat suatu konsep dalam berdakwah dengan E-Dakwah digunakan untuk generasi milenial Jakarta akan bisa ikut ke dalam syiar agama Islam yang harus terus dijalankan di masa Gambar 1 Metode Penelitian penjelasan di bawah ini : a . Tinjauan Pustaka studi tinjauan pustaka ( Putra \& Harco ," vol. 5, no. 2, pp. 26-33, 2021.

[26] N. K. Dewi, I. Mulyana, A. S. Putra, and F. R. Radita, “Tampilan Konsep Robot Penjaga Toko Di Kombinasikan Dengan Pengendalian Virtual Reality (VR) Jarak Jauh,” J. IKRA-ITH Inform., vol. 5, no. 1, pp. 33-38, 2021, [Online]. Available: 
https://journals.upi-yai.ac.id/index.php/ikraith-informatika/article/view/911/702.

[27] N. K. Dewi and A. S. Putra, "PENERIMAAN KARYAWAN BARU DENGAN," vol. 6, no. 2, pp. 154-160, 2020.

[28] T. Durand, X. He, I. Pop, and L. Robinault, Utilizing deep object detector for video surveillance indexing and retrieval, vol. 11296 LNCS. Springer International Publishing, 2019.

[29] M. A. Elliott, C. J. Baughan, and B. F. Sexton, "Errors and violations in relation to motorcyclists' crash risk," Accid. Anal. Prev., vol. 39, no. 3, pp. 491-499, 2007, doi: 10.1016/j.aap.2006.08.012.

[30] J. Gao and H. Tembine, "Distributed Mean-Field-Type Filters for Traffic Networks," IEEE Trans. Intell. Transp. Syst., vol. 20, no. 2, pp. 507-521, 2019, doi: 10.1109/TITS.2018.2816811.

[31] B. Garau, A. Alvarez, and G. Oliver, "Path planning of autonomous underwater vehicles in current fields with complex spatial variability: An A* approach,” Proc. - IEEE Int. Conf. Robot. Autom., vol. 2005, no. April, pp. 194-198, 2005, doi: 10.1109/ROBOT.2005.1570118.

[32] S. Gardens and P. E. A. Hofsass, "United States Patent (19)," no. 19, 1995.

[33] K. Garg, N. Ramakrishnan, A. Prakash, and T. Srikanthan, "Rapid and Robust Background Modeling Technique for Low-Cost Road Traffic Surveillance Systems," IEEE Trans. Intell. Transp. Syst., vol. 21, no. 5, pp. 2204-2215, 2020, doi: 10.1109/TITS.2019.2917560.

[34] P. Giannakeris, V. Kaltsa, K. Avgerinakis, A. Briassouli, S. Vrochidis, and I. Kompatsiaris, "Speed estimation and abnormality detection from surveillance cameras," IEEE Comput. Soc. Conf. Comput. Vis. Pattern Recognit. Work., vol. 2018-June, pp. 9399, 2018, doi: 10.1109/CVPRW.2018.00020.

[35] M. G. Gnoni, A. Rollo, and P. Tundo, "A smart model for urban ticketing based on RFID applications," IEEM 2009 - IEEE Int. Conf. Ind. Eng. Eng. Manag., pp. 2353-2357, 2009, doi: 10.1109/IEEM.2009.5373004.

[36] E. Guerra, "Planning for Cars That Drive Themselves: Metropolitan Planning Organizations, Regional Transportation Plans, and Autonomous Vehicles," J. Plan. Educ. Res., vol. 36, no. 2, pp. 210-224, 2016, doi: 10.1177/0739456X15613591.

[37] G. Guido, V. Gallelli, D. Rogano, and A. Vitale, "Evaluating the accuracy of vehicle tracking data obtained from Unmanned Aerial Vehicles," Int. J. Transp. Sci. Technol., vol. 5, no. 3, pp. 136-151, 2016, doi: 10.1016/j.ijtst.2016.12.001.

[38] G. Guido, A. Vitale, F. F. Saccomanno, V. Astarita, and V. Giofrè, "Vehicle Tracking System based on Videotaping Data," Procedia - Soc. Behav. Sci., vol. 111, pp. 1123-1132, 2014, doi: 10.1016/j.sbspro.2014.01.147.

[39] H. Gunawan and Lynawati, "Analisis Penerimaan Teknologi 'Smart City' Kota Purwokerto Dengan Model Technology Acceptance Model (TAM)," Konf. Nas. Sist. Inf., pp. 129-134, 2018, [Online]. Available: http://jurnal.atmaluhur.ac.id/index.php/knsi2018/article/view/347/272.

[40] C. El Hatri and J. Boumhidi, "Fuzzy deep learning based urban traffic incident detection," 2017 Intell. Syst. Comput. Vision, ISCV 2017, 2017, doi: 10.1109/ISACV.2017.8054903.

[41] Hanok Mandaku, "Studi Penerapan Intelligent Transportation System ( Its )," vol. 04, no. 1, 2010.

[42] J. Z. Hernández, S. Ossowski, and A. García-Serrano, "Multiagent architectures for intelligent traffic management systems," Transp. Res. Part C Emerg. Technol., vol. 10, no. 5-6, pp. 473-506, 2002, doi: 10.1016/S0968-090X(02)00032-3.

[43] J. I. Hernández-Vega, E. R. Varela, N. H. Romero, C. Hernández-Santos, J. L. S. Cuevas, and D. G. P. Gorham, Internet of things (IoT) for monitoring air pollutants with an unmanned aerial vehicle (UAV) in a smart city, vol. 213. Springer International Publishing, 2018.

[44] G. T. S. Ho, Y. P. Tsang, C. H. Wu, W. H. Wong, and K. L. Choy, "A computer vision-based roadside occupation surveillance system for intelligent transport in smart cities," Sensors (Switzerland), vol. 19, no. 8, 2019, doi: 10.3390/s19081796.

[45] Y. Huang, Z. Liu, M. Jiang, X. Yu, and X. Ding, "Cost-Effective Vehicle Type Recognition in Surveillance Images with Deep Active Learning and Web Data," IEEE Trans. Intell. Transp. Syst., vol. 21, no. 1, pp. 79-86, 2020, doi: 10.1109/TITS.2018.2888698.

[46] N. K. Jain, R. K. Saini, and P. Mittal, A review on traffic monitoring system techniques, vol. 742. Springer Singapore, 2019.

[47] José Miguel Cisneros Herreros and Germán Peñalva Moreno, “Article in Press Article in Press," GEF Bull. Biosci., vol. 1, no. 1, pp. 1-6, 2010, doi: 10.1016/j.jinf.2020.02.020.

[48] R. Kala and K. Warwick, "Motion planning of autonomous vehicles in a non-autonomous vehicle environment without speed lanes," Eng. Appl. Artif. Intell., vol. 26, no. 5-6, pp. 1588-1601, 2013, doi: 10.1016/j.engappai.2013.02.001.

[49] Kenny, "United States Patent (19) 11 Patent Number: 5,348,136," no. 19, pp. 1992-1995, 1993.

[50] H. J. Kim, "Vehicle detection and speed estimation for automated traffic surveillance systems at nighttime," Teh. Vjesn., vol. 26, no. 1, pp. 87-94, 2019, doi: 10.17559/TV-20170827091448.

[51] K. J. Kim, P. K. Kim, Y. S. Chung, and D. H. Choi, "Multi-Scale Detector for Accurate Vehicle Detection in Traffic Surveillance Data," IEEE Access, vol. 7, pp. 78311-78319, 2019, doi: 10.1109/ACCESS.2019.2922479.

[52] S. W. Kim, W. Liu, M. H. Ang, E. Frazzoli, and D. Rus, "The Impact of Cooperative Perception on Decision Making and Planning of Autonomous Vehicles," IEEE Intell. Transp. Syst. Mag., vol. 7, no. 3, pp. 39-50, 2015, doi: 10.1109/MITS.2015.2409883.

[53] T. Kumar and D. S. Kushwaha, "An intelligent surveillance system based on IoT for internal security of a nation," Int. J. Inf. Secur. Priv., vol. 13, no. 3, pp. 1-30, 2019, doi: 10.4018/IJISP.201907010101.

[54] M. D. Lee and D. E. Us, "United States Patent Number :," no. 19, pp. 1-3, 2010.

[55] X. Li, J. Niu, S. Kumari, F. Wu, and K. K. R. Choo, "A robust biometrics based three-factor authentication scheme for Global Mobility Networks in smart city,” Futur. Gener. Comput. Syst., vol. 83, pp. 607-618, 2018, doi: 10.1016/j.future.2017.04.012.

[56] M. Likhachev and D. Ferguson, "Planning long dynamically-feasible maneuvers for autonomous vehicles," Robot. Sci. Syst., vol. 4, pp. 214-221, 2009, doi: 10.15607/rss.2008.iv.028.

[57] M. Lu et al., "Cooperative and connected intelligent transport systems for sustainable European road transport Citation for published version (APA): Cooperative and Connected Intelligent Transport Systems for Sustainable European Road Transport," no. 2018, 2018, [Online]. Available: www.tue.nl/taverne.

[58] Z. Lv, X. Li, W. Wang, B. Zhang, J. Hu, and S. Feng, "Government affairs service platform for smart city," Futur. Gener. Comput. Syst., vol. 81, pp. 443-451, 2018, doi: 10.1016/j.future.2017.08.047. 
[59] S. Lyu et al., "UA-DETRAC 2018: Report of AVSS2018 IWT4S Challenge on Advanced Traffic Monitoring," Proc. AVSS 2018 - 2018 15th IEEE Int. Conf. Adv. Video Signal-Based Surveill., pp. 1-7, 2019, doi: 10.1109/AVSS.2018.8639089.

[60] V. C. Maha Vishnu, M. Rajalakshmi, and R. Nedunchezhian, "Intelligent traffic video surveillance and accident detection system with dynamic traffic signal control," Cluster Comput., vol. 21, no. 1, pp. 135-147, 2018, doi: 10.1007/s10586-0170974-5.

[61] V. Mayya and A. Nayak, Summarization for Detecting Traffic Rules Violators Using R-CNN. Springer Singapore, 2018.

[62] V. A. Memos, K. E. Psannis, Y. Ishibashi, B. G. Kim, and B. B. Gupta, "An Efficient Algorithm for Media-based Surveillance System (EAMSuS) in IoT Smart City Framework,” Futur. Gener. Comput. Syst., vol. 83, no. 2018, pp. 619-628, 2018, doi: 10.1016/j.future.2017.04.039.

[63] A. Mhalla, T. Chateau, S. Gazzah, and N. E. Ben Amara, "An Embedded Computer-Vision System for Multi-Object Detection in Traffic Surveillance," IEEE Trans. Intell. Transp. Syst., vol. 20, no. 11, pp. 4006-4018, 2019, doi: 10.1109/TITS.2018.2876614.

[64] J. S. B. Mitchell, D. W. Payton, and D. M. Keirsey, "Planning and reasoning for autonomous vehicle control," Int. J. Intell. Syst., vol. 2, no. 2, pp. 129-198, 1987, doi: 10.1002/int.4550020204.

[65] Muhammad Syarif Hartawan, Arman Syah Putra, and Ayub Muktiono, "Smart City Concept for Integrated Citizen Information Smart Card or ICISC in DKI Jakarta," Int. J. Sci. Technol. Manag., vol. 1, no. 4, pp. 364-370, 2020, doi: 10.46729/ijstm.v1i4.76.

[66] A. Murtaza, S. J. Hussain Pirzada, L. Jianwei, and T. Xu, "Air traffic surveillance using IP-Based space information network," 2019 28th Wirel. Opt. Commun. Conf. WOCC 2019 - Proc., no. May, 2019, doi: 10.1109/WOCC.2019.8770697.

[67] V. Murugan, V. R. Vijaykumar, and A. Nidhila, "A deep learning RcNn approach for vehicle recognition in traffic surveillance system," Proc. 2019 IEEE Int. Conf. Commun. Signal Process. ICCSP 2019, pp. 157-160, 2019, doi: 10.1109/ICCSP.2019.8698018.

[68] P. G. V. Naranjo, Z. Pooranian, M. Shojafar, M. Conti, and R. Buyya, "FOCAN: A Fog-supported smart city network architecture for management of applications in the Internet of Everything environments," J. Parallel Distrib. Comput., vol. 132, pp. 274-283, 2019, doi: 10.1016/j.jpdc.2018.07.003.

[69] K. Nellore and G. P. Hancke, "A survey on urban traffic management system using wireless sensor networks," Sensors (Switzerland), vol. 16, no. 2, 2016, doi: 10.3390/s16020157.

[70] B. Nemade, “Automatic Traffic Surveillance Using Video Tracking,” Procedia Comput. Sci., vol. 79, pp. 402-409, 2016, doi: 10.1016/j.procs.2016.03.052.

[71] K. Nguyen et al., "Vehicle Re-identification with Learned Representation and Spatial Verification and Abnormality Detection with Multi-Adaptive Vehicle Detectors for Traffic Video Analysis," Proc. IEEE Comput. Soc. Conf. Comput. Vis. Pattern Recognit. Work., pp. 363-372, 2019.

[72] S. Parekh, N. Dhami, S. Patel, and J. Undavia, "Traffic signal automation through iot by sensing and detecting traffic intensity through ir sensors," Smart Innov. Syst. Technol., vol. 106, pp. 53-65, 2019, doi: 10.1007/978-981-13-1742-2_6.

[73] D. Parker, J. T. Reason, A. S. R. Manstead, and S. G. Stradling, "Driving errors, driving violations and accident involvement," Ergonomics, vol. 38, no. 5, pp. 1036-1048, 1995, doi: 10.1080/00140139508925170.

[74] S. D. Pendleton et al., "Perception, planning, control, and coordination for autonomous vehicles," Machines, vol. 5, no. 1, pp. 1-54, 2017, doi: 10.3390/machines5010006.

[75] R. B. Pendor and P. P. Tasgaonkar, "An IoT framework for intelligent vehicle monitoring system," Int. Conf. Commun. Signal Process. ICCSP 2016, pp. 1694-1696, 2016, doi: 10.1109/ICCSP.2016.7754454.

[76] S. Pohlmann and U. Traenkle, "Orientation in road traffic. Age-related differences using an in-vehicle navigation system and a conventional map," Accid. Anal. Prev., vol. 26, no. 6, pp. 689-702, 1994, doi: 10.1016/0001-4575(94)90048-5.

[77] P. Polack, F. Altche, B. DAndrea-Novel, and A. De La Fortelle, "The kinematic bicycle model: A consistent model for planning feasible trajectories for autonomous vehicles?," IEEE Intell. Veh. Symp. Proc., no. Iv, pp. 812-818, 2017, doi: 10.1109/IVS.2017.7995816.

[78] A. Pongpunwattana and R. Rysdyk, "Real-time planning for multiple autonomous vehicles in dynamic uncertain environments," J. Aerosp. Comput. Inf. Commun., vol. 1, no. DEC., pp. 580-604, 2004, doi: 10.2514/1.12919.

[79] A. S. Putra and F. R. Radita, "Paradigma Belajar Mengaji Secara Online Pada Masa Pandemic Coronavirus Disease 2019

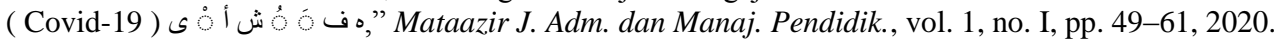

[80] H. Lisnawati and A. Sinaga, "Data mining with associated methods to predict consumer purchasing patterns," Int. J. Mod. Educ. Comput. Sci., vol. 12, no. 5, pp. 16-28, 2020, doi: 10.5815/ijmecs.2020.05.02.

[81] M. Mitra and A. Chowdhury, "A modernized voting system using fuzzy logic and blockchain technology," Int. J. Mod. Educ. Comput. Sci., vol. 12, no. 3, pp. 17-25, 2020, doi: 10.5815/ijmecs.2020.03.03.

[82] S. Sathasivam, S. A. Alzaeemi, and M. Velavan, "Mean-field theory in hopfield neural network for doing 2 satisfiability logic programming," Int. J. Mod. Educ. Comput. Sci., vol. 12, no. 4, pp. 27-39, 2020, doi: 10.5815/ijmecs.2020.04.03.

[83] Y. Sulema, E. E. Kerre, and O. Shkurat, "Vector image retrieval methods based on fuzzy patterns," Int. J. Mod. Educ. Comput. Sci., vol. 12, no. 3, pp. 8-16, 2020, doi: 10.5815/ijmecs.2020.03.02.

[84] A. O. Eboka and A. A. Ojugo, "Mitigating technical challenges via redesigning campus network for greater efficiency, scalability and robustness: A logical view," Int. J. Mod. Educ. Comput. Sci., vol. 12, no. 6, pp. 29-45, 2020, doi: 10.5815/ijmecs.2020.06.03.

[85] I. Ramadhan, A. Kurniawan, and A. S. Putra, "Penentuan Pola Penindakan Pelanggaran Lalu Lintas di DKI Jakarta Menggunakan Metode Analytic Network Process ( ANP )," vol. 5, no. 1, pp. 51-57.

[86] W. Schwarting, J. Alonso-Mora, and D. Rus, "Planning and Decision-Making for Autonomous Vehicles," Annu. Rev. Control. Robot. Auton. Syst., vol. 1, no. 1, pp. 187-210, 2018, doi: 10.1146/annurev-control-060117-105157.

[87] M. Scotch and B. Parmanto, "SOVAT: Spatial OLAP visualization and analysis tool," Proc. Annu. Hawaii Int. Conf. Syst. Sci., vol. 00, no. C, p. 142, 2005, doi: 10.1109/hicss.2005.550. 
[88] B. Singh and A. Gupta, "Recent trends in intelligent transportation systems: a review," J. Transp. Lit., vol. 9, no. 2, pp. 30-34, 2015, doi: 10.1590/2238-1031.jtl.v9n2a6.

[89] T. Taleshian and S. Minagar, "Motion planning for an autonomous underwater vehicle," Conf. Proc. 2015 2nd Int. Conf. Knowledge-Based Eng. Innov. KBEI 2015, pp. 285-290, 2016, doi: 10.1109/KBEI.2015.7436061.

[90] D. N. N. Tran, L. H. Pham, H. M. Tran, and S. V. U. Ha, "Probabilistic model and neural network for scene classification in traffic surveillance system," Adv. Intell. Syst. Comput., vol. 672, no. June, pp. 685-695, 2018, doi: 10.1007/978-981-10-75124_68.

[91] V. Tsakanikas and T. Dagiuklas, "Video surveillance systems-current status and future trends," Comput. Electr. Eng., vol. 70, pp. 736-753, 2018, doi: 10.1016/j.compeleceng.2017.11.011.

[92] V. Tsakanikas and T. Dagiuklas, "Video surveillance systems-current status and future trends," Comput. Electr. Eng., vol. 70, pp. 736-753, 2018, doi: 10.1016/j.compeleceng.2017.11.011.

[93] P. Wang, L. Li, Y. Jin, and G. Wang, "Detection of unwanted traffic congestion based on existing surveillance system using in freeway via a CNN-architecture trafficnet," Proc. 13th IEEE Conf. Ind. Electron. Appl. ICIEA 2018, no. 51505037, pp. 11341139, 2018, doi: 10.1109/ICIEA.2018.8397881.

\section{Authors' Profiles}

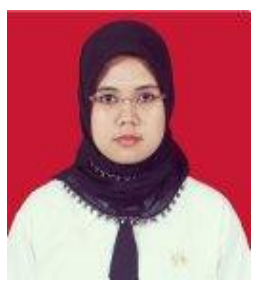

Nur Kumala Dewi born in Jombang December 20, 1980. Is the first daughter of two children of Mr. H. Achmad Karim Sueb and Mrs. Hj. Masbenul Karimah. Completing education at Madrasah Ibtidaiyah Educational Foundation (MI YASPIN), Junior High School of the Indonesian Education Foundation (SMP YANINDO) North Jakarta, SMUN 40 North Jakarta. In 2003 completed his undergraduate study (S1) at the Faculty of Computer Science, Universitas Pembangunan Nasional 'Veteran' Jakarta. In 2008, Graduated with Masters in Education Management at the State University of Jakarta (UNJ) and in 2014 completed the Doctor of Education Management Study Program at UNJ.

Recorded from 1997 to 2007 as a Teacher in the Field of English Studies at YANINDO Junior High School, YANINDO Senior High School (SMEA), Madrasah Aliyah Al Jihad. Lecturer in English and Research Methodology at STMIK Muhammadiyah Jakarta. Owner of Warung Bebek Volker H. Sueb Restaurant since 1987 in North Jakarta, Commissioner of PT. Boilerindo Karya Perkasa Jakarta and Civil Servants (PNS) at the Ministry of Religion of the Republic of Indonesia as Head of the Islamic Religious Broadcast Section of the Directorate of Information on Islamic Religion, Directorate General of Islamic Community Guidance (Ditjen Bimas Islam).

Married to Agus Mandori, ST., MM President Director of PT. Boilerindo Karya Perkasa Jakarta and blessed with one daughter and three sons, namely: Putri Balqiest Mandori is 15 years old, an eleventh grade student (XI) at MAN 3 Tambak Beras Jombang, East Java, Salman Alfarisy Mandori is a 10 year old fourth grade student (IV) in SDIT Al Amanah, Achmad Al Gazhali Mandori is 5 years old and Achmad Alfatih Mandori is 3 years old.

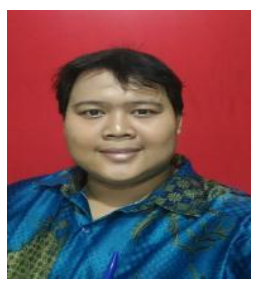

Arman Syah Putra born in Jakarta, August 31, 1985. Is the first son of two children of Mr. Agus Sumpeno and Mrs. Sulasmi. Completing his education at SDN 01 Kramat South Jakarta, Junior High School at Yanusa Middle School South Jakarta, Senior High School at SMUN 29 South Jakarta. In 2007 completed his undergraduate studies (S1) at the Faculty of Computer Science, Budi Luhur University, Jakarta. In 2009, Graduated with a Masters in Management from Bhayangkara University, Jakarta Raya in 2009 and in 2018 began his doctoral degree majoring in Computer Science at Bina Nusantara University.

Recorded from 2010 to 2020 as a lecturer at various campuses. Lecturers in Computer Science courses such as Computer Networking courses, Data mining concepts, Management information systems.

How to cite this paper: Nur Kumala Dewi, Arman Syah Putra, "Application of Greedy Algorithm on Traffic Violation Enforcement", International Journal of Education and Management Engineering (IJEME), Vol.11, No.1, pp.1-10, 2021. DOI: 10.5815/ijeme.2021.01.01 